\title{
Seasonal variation in reproductive measures of tropical Roseate Terns Sterna dougallif: previously undescribed breeding patterns in a seabird
}

\author{
JAIME A. RAMOS \\ Instituto Politécnico de Bragança, Escola Superior Agrária, Quinta de Santa Apolónia, $5301-584$ Bragança, Portugal
}

\begin{abstract}
Seasonal variation in egg-laying, egg size, hatching success, hatchling mass, fledging success and chick growth of Roseate Terns Sterna dougallii breeding on Aride Island (Seychelles), Indian Ocean, were studied in 1997 and 1998. I investigated to what extent two patterns, common in a range of species, were followed by tropical Roseate Terns: (a) seasonal decrease in clutch size, egg size and breeding success and (b) an increase in breeding success with increasing egg weight. In 1997 (a poor year), the earliest nesting birds laid significantly smaller eggs, and chicks were lighter at hatching than those of peak nesting birds. The mean clutch size, of 1.04 eggs, showed no seasonal variation and no ' $b$ '-eggs hatched. In 1998 (a good year) the earliest nesting birds laid eggs of similar size and their chicks were of similar weight to those of peak nesting birds. Mean clutch size, of 1.25 eggs, increased significantly through the season and about $60 \%$ of the ' $b$ '-eggs hatched. In 1997, hatching success was $57 \%$ whereas in 1998 it was $80 \%$. In both years, breeding success declined significantly through the season. The fact that the earliest breeding birds laid smaller eggs in a poor year and smaller clutches in a good year is in marked contrast to a range of other species, and to temperate-nesting Roseate Terns. Egg volume explained about half of the variance in hatchling mass in both years, but only $15 \%$ of the variation in linear growth rate. Hatching date was the only variable with a significant effect on fledging success. Roseate Terns on Aride seemed to sacrifice egg size and clutch size for earliness of laying. Presumably it is a strategy of older birds to lay as early as possible and may be regarded as a response of tropical Roseate Terns to breeding under relatively poor, and seasonally declining, food conditions.
\end{abstract}

Availability of food is one of the main factors influencing patterns of reproduction. Current theories predict that the timing of the breeding season in birds is determined by the availability of food for egg formation (Perrins 1970, 1996) and for feeding young (Lack 1966). In order to feed young when food is most abundant, parents of some species in temperate areas start their breeding cycle when food is relatively scarce. Nevertheless, studies on a range of species have shown that early breeders are the most successful (Perrins 1996).

Both tropical (Ashmole 1963a) and temperate (Furness \& Birkhead 1984) seabird numbers in particular localities have been interpreted in relation to the number of conspecifics competing for food around the

Email: jramos@ipb.pt breeding colonies. Such competition may result in prey depletion, causing adults to travel increasing distances to collect food for their chicks. The abundance of prey populations is likely to decline through the breeding season of marine terns as Safina and Burger (1985) showed for Common Terns Sterna hirundo on Long Island, USA. Apart from a decline in prey numbers, a decrease in food availability could result from seasonal changes in fish behaviour, a decline in the predators which drive prey to the surface or some other factor. An expected corollary of this seasonal decline in food availability is strong selection for early breeding.

Many field studies have reported seasonal declines in different aspects of reproductive performance, such as egg size, clutch size, hatching success and fledging success (Burger et al. 1996, Perrins 1996 and references therein). Previous studies indicate also that the 
earliest breeding seabirds tend to be the older, more experienced birds, and that they lay the largest clutches and the largest eggs (Nisbet \& Cohen 1975, Burger et al. 1996, Perrins 1996) and, in the absence of predation, they are consistently the most successful (Nisbet \& Welton 1984). Since hatching weight is closely correlated with egg size, nestlings hatching from large eggs have an initial advantage over those hatching from small eggs. This advantage may be increased if adults which lay large eggs are also more efficient at feeding chicks (Reid \& Boersma 1990, Bolton 1991, Magrath 1992, Williams 1994). However, much of the available information concerns temperate populations. Chicks of tropical seabirds commonly encounter periods of food shortage, and often die of starvation or fledge underweight (Ashmole 1963b, Feare 1976, Harris 1977). Variation in reproductive measures over the entire breeding season has not been fully documented for many tropical seabirds.

This paper compares two breeding seasons in terms of egg-laying patterns, egg size, clutch size, hatching success, hatchling mass, chick growth and fledging success for tropical Roseate Terns Sterna dougallii breeding on Aride, Seychelles. Emphasis was placed on: (a) seasonal changes in egg size, clutch size and breeding success, and (b) the effect of egg weight on breeding success.

\section{STUDY AREA AND METHODS}

Aride Island $\left(4^{\circ} 10^{\prime} \mathrm{S}, 55^{\circ} 40^{\prime} \mathrm{E}\right.$ ), with $73.2 \mathrm{ha}$, is a Royal Society for Nature Conservation nature reserve. It is the northernmost of the granitic islands of the Seychelles archipelago, comprising a densely forested plateau and hill, rising to $151 \mathrm{~m}$ (Warman \& Todd 1984). Most Roseate Terns nested under a canopy of Pisonia grandis trees close to rocks or logs, and were on average $0.5 \mathrm{~m}$ from the nearest neighbour (Ramos 1998a). Nests were studied in a large colony (1000-1300 pairs) and in three nearby small colonies (8-12 pairs).

Two quadrats were established in the main colony, with corner posts and string, 16 days after the first egg was seen; one peripheral and less dense quadrat $\left(49 \mathrm{~m}^{2}\right.$, 0.63 and 0.35 nests $/ \mathrm{m}^{2}$ ) and one slightly more central and denser quadrat $\left(64 \mathrm{~m}^{2}, 1.23\right.$ and 1.43 nests $\left./ \mathrm{m}^{2}\right)$. To increase the sample size, another plot of about $25 \mathrm{~m}^{2}$, adjacent to the peripheral quadrat, was added $4-6$ days later (these data are included in the peripheral quadrat). All nests in these plots and in the small colonies were marked with numbered pegs. The two quadrats were visually isolated from each other by rocky barriers. Only the birds in the quadrats were visited, although a few neighbours left their nests during my visits.

Study quadrats and small colonies were visited daily for up to 25 minutes, keeping disturbance to a minimum. In two-egg clutches, eggs were marked with a waterproof non-toxic marker. All eggs were measured with calipers (length and breadth to $0.1 \mathrm{~mm}$ ). An index of egg volume was calculated as (length $x$ breadth ${ }^{2} / 1000$. Until the end of the hatching period, all new nests that were found were marked. In two-egg clutches, eggs were classified as 'a' (the first egg laid or the first egg to hatch) and ' $b$ '. Chicks were ringed and weighed at hatching (day 0). Thereafter I searched for chicks daily and weighed them whenever they were encountered. As a response to disturbance, from 3-5 days old, chicks had a tendency to disperse into rocky areas. To encourage chicks to stay at their nest sites, small shelters made of stones and dead wood were constructed for any less concealed sites of newly hatched chicks. Chicks were weighed using $50 \mathrm{~g}$ and $300 \mathrm{~g}$ Pesola spring balances. Chicks were weighed to the nearest 0.1 or $0.2 \mathrm{~g}$ until they reached $50 \mathrm{~g}$, and to the nearest $0.5 \mathrm{~g}$ thereafter.

Nests were marked 16 days after the first egg was seen to avoid disturbance during the first two weeks of incubation. However, egg loss prior to nest marking and disturbance in the study quadrats could have affected the study of breeding patterns. To control for these effects, all nests in a defined study plot of about 180-200 $\mathrm{m}^{2}$ were mapped from a permanent hide at the time of egg-laying. One to three hours were spent each day mapping the position of each new clutch and monitoring the fate of eggs and chicks. This is referred to as the hide area. Without disturbance, most chicks remained at their nest sites until they fledged or died. Small chicks could be strongly pecked by other adults if they wandered from the territory, or on their own territory when left unguarded by their parents. The number of chicks with signs of pecking (pecked chicks often lost down on the back and had blood on the head) were noted and compared with those examined in the study quadrats. Chicks found dead or which disappeared after being badly pecked were regarded as having died through pecking. Chicks were also infested with ticks (Amblyomma loculosum, tick description in Hoogstraal et al. 1976) in July. Chicks with signs of tick infestation in the hide area (ticks were usually attached on one foot and chicks were reluctant to stand on the affected foot) and those chicks examined with ticks in the study quadrats were noted.

For analysis of seasonal variation in reproductive measures, the egg-laying season was divided into 
periods of six days, based on the date of hatching of the first egg. The date of egg-laying was back-calculated using an incubation period of 22 days (Maul 1998). Seasonal variation in hatching success (percentage of eggs in completed clutches that hatched) was determined for the hide area because laying dates were not known for the study quadrats. Seasonal variation in egg size and hatchling mass was examined for 'a'-eggs. Linear growth rate was defined as the slope of a regression line of chick mass against date during the quasi-linear growth-period (3-14 days for chicks with normal development, Nisbet et al. 1995). Periods of relatively rapid growth were curtailed by periods of low food delivery to chicks (food shortage, Ramos 2000). Linear growth rate was calculated only for chicks with at least four data points, for the periods of 'good' food supply (1997: 22 June to 6 July; 1998: 9-30 June) and for the periods of food shortage (1997: after 6 July; 1998: 1-6 July).

Measurements of eggs which hatched were compared by $t$-test with those that did not hatch. Kruskal-Wallis, contingency chi-squared tests and oneway ANOVA were used to analyse differences in reproductive measures among six-day periods. Correlations of linear growth rate with egg volume and hatchling mass were examined with Pearson correlation coefficients. Logistic regression was used to assess the multivariate contribution of egg volume, hatching date, hatchling mass and clutch size in explaining fledging success of ' $a$ '-chicks in 1998 (virtually all 'b'-chicks died in 1998 and, in 1997, virtually no chicks fledged, see results). The ' $a$ '-chicks were classified as fledged or unfledged. Fledged chicks were counted as those that were not losing weight when last weighed at more than five days, and were not found dying in the area around the quadrats and subcolonies (Nisbet et al. 1990). The parameters of the best model were obtained by the maximum likelihood method (Cox 1970).

\section{RESULTS}

\section{Disturbance}

Overall, there was no significant difference between the hatching success in the hide area and that in the study quadrats in either $1997(56.7 \%, n=171$ and $\left.62.3 \%, n=154, \chi^{2}{ }_{1}=0.84\right)$ or $1998(81.4 \%, n=194$ and $76.6 \%, n=175, \chi^{2}{ }_{1}=1.04$; both ns, with Yates correction). Hatching success in the study quadrats does not take account of egg loss prior to nest marking. However, nest mapping in 1997 showed that only nine eggs were lost in the hide area (with one pair relaying) before nests were marked in the study quadrats. Since 148 nests were mapped before nests were marked, probably only about $5.4 \%$ of the nests would have been lost in the quadrats and small colonies prior to nest marking. This is a small error that would not have affected the results of the analysis. In 1998 fewer than eight eggs were lost prior to nest marking.

When disturbed, adults flew up and some chicks ran away or hid. This could increase chick mortality through adult aggression. This aspect was evaluated in 1997. Of the 44 chicks that had left their nests, 24 were found in a different site 5-16 days later and/or found dying during the period of acute food shortage. Even if it is presumed that all the chicks that disappeared $(20.8 \%, n=96)$ were killed by adults, this did not differ significantly from the proportion of chicks presumed to have been killed directly or indirectly by adults in the hide area $\left(19.6 \%, n=97, \chi^{2}{ }_{1}=1.23\right.$, ns, with Yates correction). Artificial shelters and the rugged terrain may have reduced movements of some chicks and thereby reduced chick mortality from adult aggression. These results indicate that marking nests 16 days after the first egg was laid had no significant influence on the study of nesting patterns, and disturbance induced by research activities had no significant influence on the study of breeding success.

\section{Seasonal variation in breeding parameters}

Egg-laying was significantly earlier in 1998 than in 1997 (median test $\chi^{2}{ }_{1}=4.09, P<0.05$, with Yates correction; Fig. 1). The mapping of nests in the hide area demonstrated that the number of nests initiated declined significantly through the season in both 1997 $\left(\chi^{2}{ }_{4}=144.60, P<0.001\right)$ and $1998\left(\chi^{2}{ }_{3}=174.0\right.$, $P<0.001$ ). In both years, $90-95 \%$ of the nests were initiated in the first 18 days of laying, in a season lasting 36 days in all (Fig. 1).

Clutch size (mean $\pm \mathrm{sd}$ ) was higher in $1998(1.25 \pm$ $0.44, n=114)$ than in $1997(1.04 \pm 0.20, n=105)$. In 1997 it showed no significant seasonal variation (Kruskal-Wallis $H=0.87$, ns) but in 1998 it was significantly higher for peak nesting birds than for the earliest or for late nesting birds (Kruskal-Wallis $H=$ 19.37, $P<0.001$; Fig. 2).

The length, breadth and volume of the eggs which survived in 1997 and 1998 were similar to those which were lost (Table 1). As expected ' $b$ '-eggs were significantly smaller than ' $a$ '-eggs ( $t$-test of the volume index data $=2.56, P<0.01$, Table 1). The volume index of eggs and hatchling mass in 1997 varied significantly 

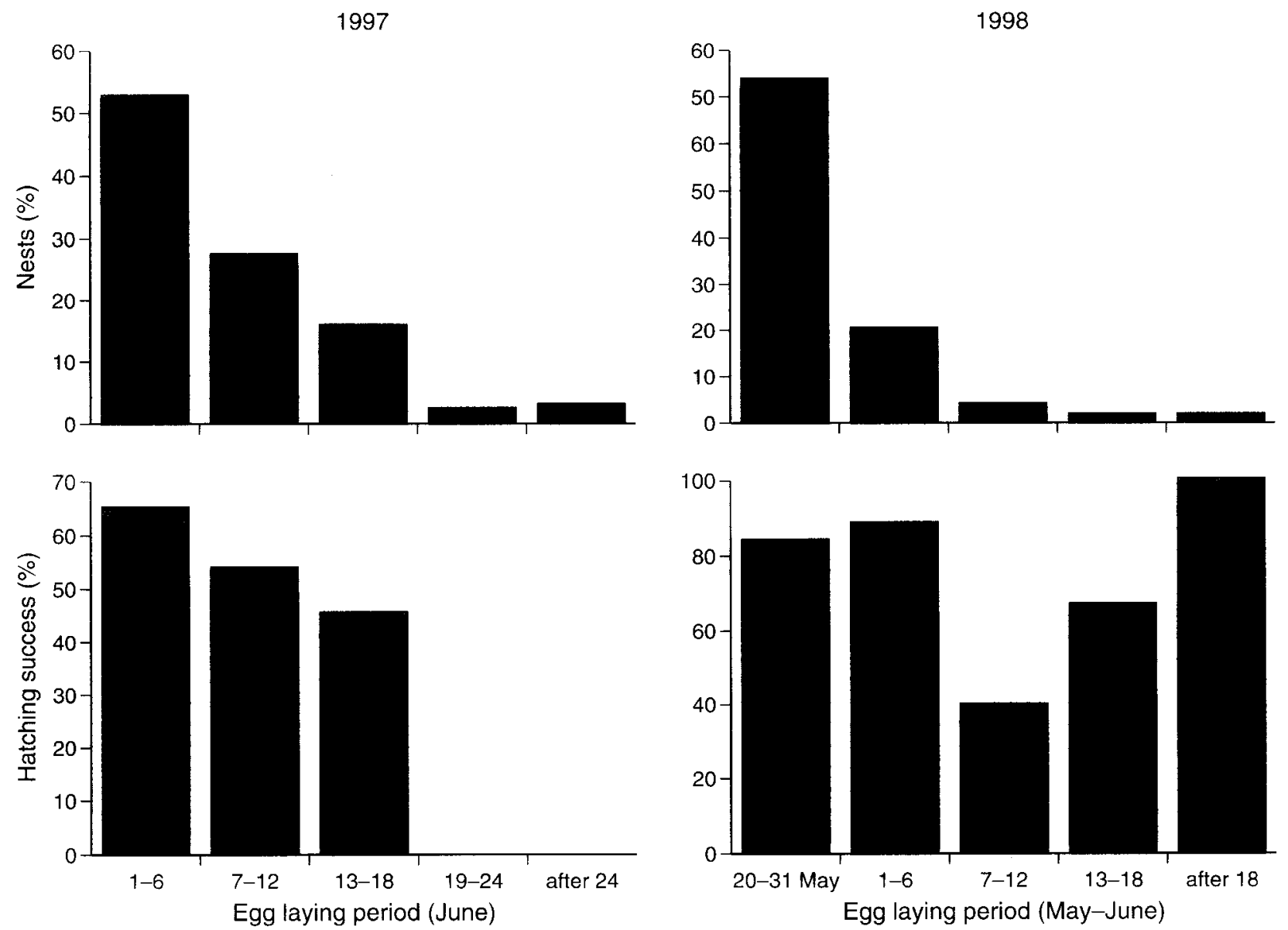

Figure 1. Comparison of seasonal variation in egg-laying and hatching success of Roseate Terns on Aride Island in 1997 ( $n=164$ nests, 171 eggs) and 1998 ( $n=154$ nests, 194 eggs). Nests were mapped by laying date and grouped in six-day periods (data for the first two periods of 1998 were not separated).

through the season (one-way ANOVA, $F_{4,113}=5.56$ and $F_{3,98}=8.44, P<0.01$ ), with smaller eggs and lighter chicks in the first six-day period, followed by larger eggs and heavier chicks in the following two to three six-day periods, and again smaller eggs and lighter chicks in the final period. Egg size ('a'-eggs) showed no seasonal variation in 1998 (one-way ANOVA, $F_{4,102}=$ $0.47, \mathrm{~ns})$, being similar to that of the middle periods of

Table 1. Comparison of measurements (mean $\pm s d$ ) and volume index ( $=$ length $\times$ breadth $2 / 1000)$ between hatched and non-hatched eggs of Roseate Terns on Aride Island in 1997 and 1998.

\begin{tabular}{lrrr}
\hline & Length $(\mathrm{mm})$ & Breadth $(\mathrm{mm})$ & Volume index $\left(\mathrm{cm}^{3}\right)$ \\
$\mathbf{1 9 9 7}$ 'a'-eggs & & & \\
Hatched eggs $(n=88)$ & $41.06 \pm 1.76$ & $28.81 \pm 0.95$ & $34.13 \pm 2.90$ \\
Non-hatched eggs $(n=77)$ & $41.26 \pm 1.73$ & $28.50 \pm 1.51$ & $33.55 \pm 3.59$ \\
$t$-test & $0.71 \mathrm{~ns}$ & $1.57 \mathrm{~ns}$ & $1.14 \mathrm{~ns}$ \\
$\mathbf{1 9 9 8}$ 'a'-eggs & & $28.97 \pm 0.87$ & $34.29 \pm 2.74$ \\
Hatched eggs $(n=106)$ & $40.80 \pm 1.62$ & $29.10 \pm 0.86$ & $34.42 \pm 3.07$ \\
Non-hatched eggs $(n=26)$ & $40.56 \pm 2.05$ & $0.73 \mathrm{~ns}$ & $0.22 \mathrm{~ns}$ \\
$t$-test & $0.64 \mathrm{~ns}$ & $28.79 \pm 0.88$ & $32.88 \pm 2.66$ \\
$\mathbf{1 9 9 8}$ 'b'-eggs & $39.61 \pm 1.54$ & & \\
$1998(n=30)$ & &
\end{tabular}


1997 (Fig. 2). Hatchling mass showed a significant seasonal decline (one-way ANOVA, $F_{4,106}=4.97, P<0.001$ )
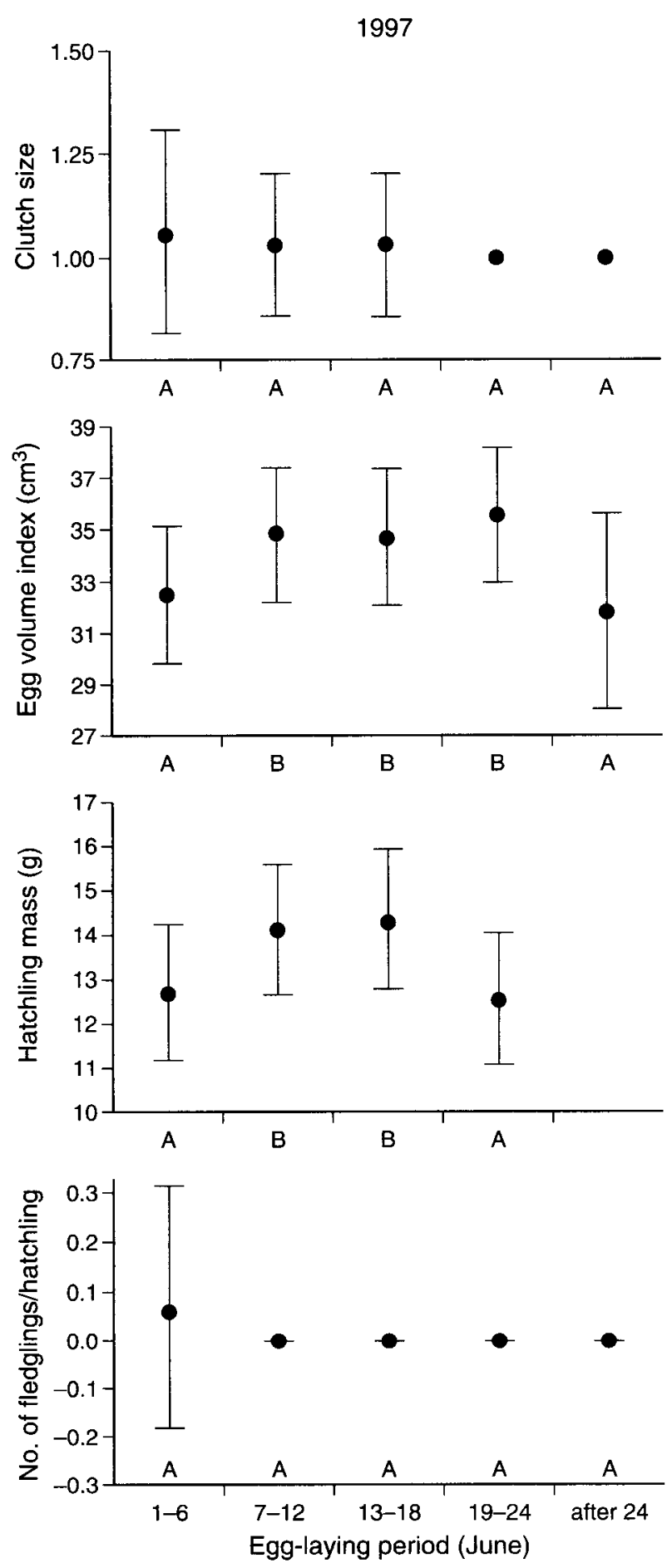

because hatchlings in the final period differed significantly from those in the remaining four periods (Fig. 2).
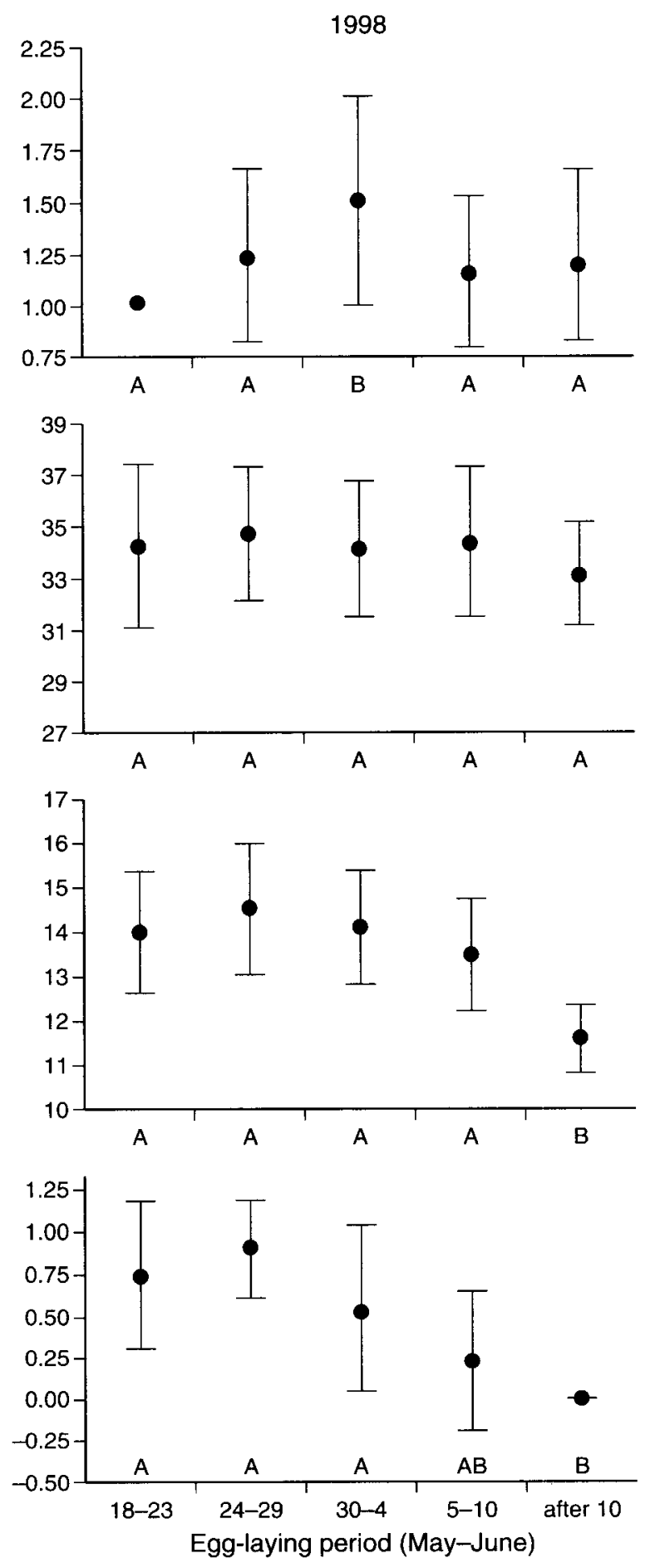

Figure 2. Seasonal variation in reproductive measures of Roseate Terns on Aride Island in 1997 and 1998. Dates indicate period (sixdays) of egg-laying. Periods sharing the same letter did not differ significantly (all comparisons $P<0.05$, Newman-Keuls test for continuous variables and paired median test for categorical variables). 
In the hide area (where nests were mapped by laying date), hatching success was significantly lower in 1997 $(56.7 \%, n=171)$ than in $1998\left(81.4 \%, n=194, \chi^{2}{ }_{1}=\right.$ $24.13, P<0.001$, with Yates correction). In both years, it declined significantly through the season (1997: $\chi^{2}{ }_{2}$ $=6.75$; 1998: $\chi_{2}^{2}=7.7, P<0.05$; Fig. 1). In 1997 no 'b'-eggs $(n=5)$ hatched, compared with $59 \%(n=34)$ in 1998. In 1997 eggs were left unattended for up to four hours and some were eaten by skinks (Mabuya wrightii and $M$. sechellensis). Although unable to bite an intact egg, skinks on 16 occasions were seen to roll an unattended egg with their head until the egg broke against a jagged rock. In 1998 no eggs were observed being eaten by skinks, despite similar observation periods to those in 1997, because virtually no eggs were left unattended by the terns. This annual difference in egg predation by skinks was significant $\left(\chi^{2}{ }_{1}=14.06\right.$, $P<0.001$, with Yates correction).

In 1997, only two chicks fledged from 164 marked nests. At 38 days they weighed 73.5 and $68.5 \mathrm{~g}$, respectively, which is extremely light. Virtually all other chicks died of starvation (Ramos 1998b), most over 12 days old. Overall, $87.5 \%(n=96)$ of the chicks ringed in 1997 were weighed regularly or found dying during the period of food shortage (chicks that disappeared after several days of losing weight were considered to have starved). From these, the proportion of chicks that reached 15 days was significantly higher for chicks from the first six-day period of hatching (22-27 June), than for those in the periods 28 June to 3 July and after 4 July $\left(\chi_{2}^{2}=57.25, P<0.001\right.$, Table 2$)$.
Table 2. Seasonal variation in the proportion of the 1997 chicks that reached 15 days and fledged.

\begin{tabular}{lccc}
\hline $\begin{array}{l}\text { Hatching } \\
\text { period }\end{array}$ & $\begin{array}{c}\text { Number of chicks } \\
\text { encountered } \\
\text { regularly }\end{array}$ & $\begin{array}{c}\% \text { reaching } \\
15 \text { days }\end{array}$ & $\begin{array}{c}\text { Number } \\
\text { fledged }\end{array}$ \\
\hline 22-27 June & 22 & 86.4 & 2 \\
28 June -3 July & 24 & 50.0 & 0 \\
4-9 July & 32 & 0 & 0 \\
$>$ 10 July & 6 & 0 & 0 \\
\hline
\end{tabular}

In 1998, fledging success decreased seasonally (KruskalWallis $H=30.29, P<0.001$, Fig. 2). Virtually all 'b'chicks died before five days of age.

\section{Relationship between chick growth, egg size and breeding success}

Before the period of food shortage, linear growth rate (mean $\pm \mathrm{sd}$ ) was similar in 1997 and 1998 (1997: 4.89 $\pm 1.06 \mathrm{~g} /$ day, $n=26 ; 1998: 5.26 \pm 1.13 \mathrm{~g} /$ day, $n=44$, $t$-test $=1.36, \mathrm{~ns}$ ). The period of food shortage in 1997 lasted for at least two weeks and chicks died, whereas in 1998 the period of food shortage lasted for one week and most chicks recovered. During the periods of food shortage chicks lost weight rapidly, but weight loss was greater in $1997(-1.27 \pm 1.00 \mathrm{~g} / \mathrm{day}, n=30)$ than in 1998 $(0.87 \pm 0.80 \mathrm{~g} / \mathrm{day}, n=13, t$-test $=6.78, P<0.001)$

Egg volume explained $56 \%$ of the variance in hatchling mass in $1997\left(r_{85}=0.84, P<0.001\right)$ and $47 \%$ in $1998\left(r_{105}=0.69, P<0.001, n=105\right.$, Fig. 3). When

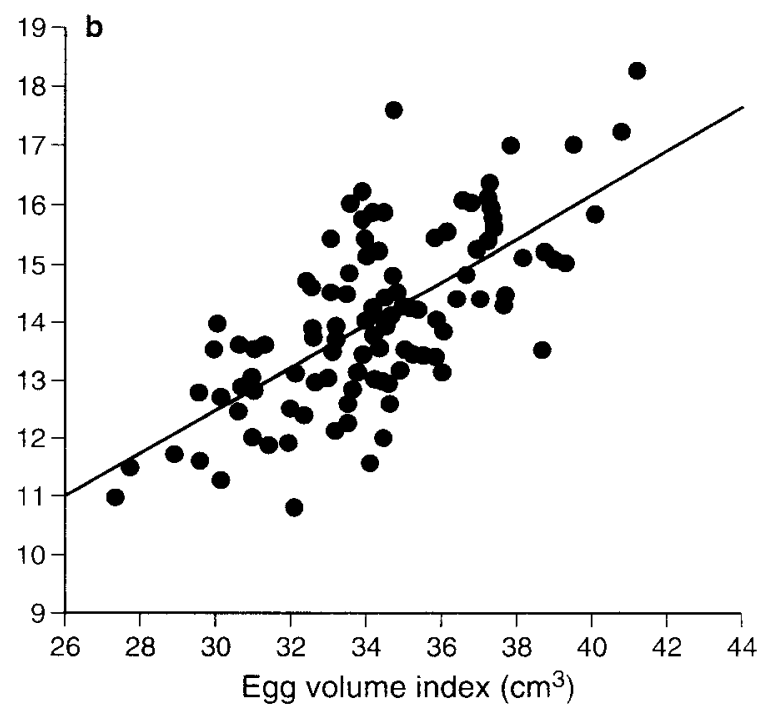

Figure 3. Relationship between egg volume and hatchling mass for Roseate Terns on Aride Island (a) in $1997(y=-0.83+0.43 x$, $n=85)$ and (b) in $1998(y=1.37+0.37 x, n=105)$. 
food seemed readily available, linear growth rate correlated significantly with egg volume (Fig. 4) but egg volume explained only $15 \%$ of the variation in linear growth rate; hatchling mass explained none of the residual variance (forward stepwise multiple regression analysis: $F_{1,59}=10.39, P<0.01$ ). Contrary to expectation, neither hatching success (Table 1) nor fledging success (Table 3) were influenced by egg volume. A logistic regression analysis of hatching date, clutch size, egg volume and hatchling mass on chick fate showed that hatching date was the only variable with a significant effect on fledging success (Table 3 ).

\section{DISCUSSION}

Unlike temperate Roseate Tern populations (Nisbet 1981), the earliest-nesting Roseate Terns laid smaller eggs in a year of poor productivity and had smaller clutches in a year of good productivity than those of peak-nesting birds. Despite this difference, Roseate Terns on Aride, like other temperate seabirds (Spendelow 1982, Nisbet \& Welton 1984, Coulson \& Porter 1985, Becker et al. 1985, Burger et al. 1996), showed a seasonal decline in the number of nests initiated and in breeding success.

The size of the Roseate Tern 'a'-eggs and linear growth rate of chicks on Aride were similar to those of ' $b$ '-eggs and ' $b$ '-chicks from temperate Roseate Terns (Nisbet 1981, Nisbet et al. 1995). Before the period of food shortage, linear growth rate was correlated

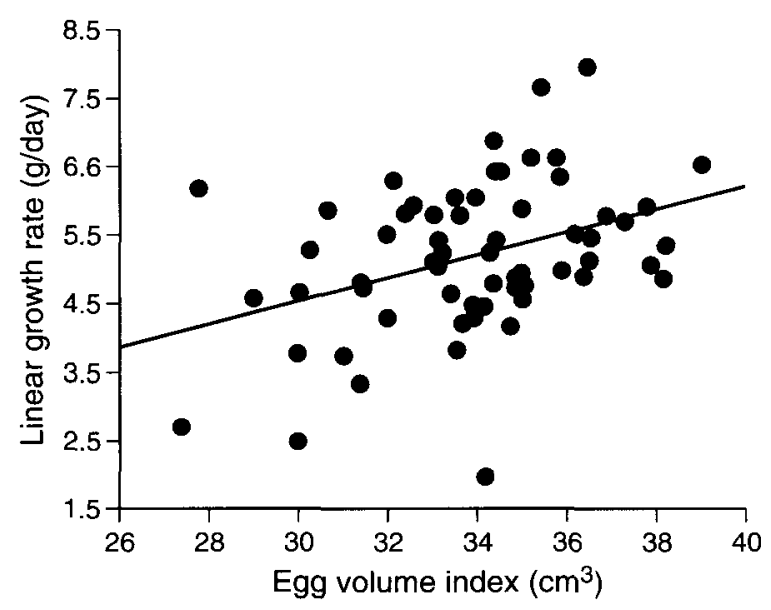

Figure 4. Relationship between linear growth rate during the period with no food shortage and egg volume for Roseate Terns on Aride Island. Data from 1997 and 1998 were combined because no significant differences in both linear growth rate and egg volume were found between years $(y=-0.49+0.17 x$, $n=62)$.
Table 3. Logistic regression analysis of chick fate $(0=$ fledged, $1=$ unfledged) as dependent variable and hatching date, egg volume, hatchling mass and clutch size as independent variables. Coefficients and $P$ values obtained with the maximum likelihood method are shown $\left(\chi^{2}{ }_{4}=27.79, P<0.001\right)$.

\begin{tabular}{lcc}
\hline Variable & Coefficient & $P$ \\
\hline Constant & 1.51 & $\mathrm{~ns}$ \\
Hatching date & -0.18 & $<0.001$ \\
Egg volume & 0.05 & $\mathrm{~ns}$ \\
Hatchling mass & 0.01 & $\mathrm{~ns}$ \\
Clutch size & -0.67 & $\mathrm{~ns}$ \\
\hline
\end{tabular}

with egg size, which may be closely related to the age and breeding experience of parents (Lequette \& Weimerskirch 1990, Croxall et al. 1992). Therefore, during this period, growth of chicks may have reflected individual parental performance and parental quality (Nisbet 1978, Furness 1983, Bolton 1991, Nisbet et al. $1995,1998)$. Contrary to studies on a range of temperate species, including Roseate Terns (Nisbet 1973, 1978, Brooke 1990, Perrins 1996, Ramos et al. 1997), breeding success was not correlated with egg size or clutch size. Feare (1976) found that the hatching success of Sooty Terns Sterna fuscata in the Seychelles was also uncorrelated with egg size, but unhatched eggs tended to be lighter than hatched eggs.

Predation by skinks was responsible for some egg losses, but there was no evidence that it contributed significantly to the seasonal decline in breeding performance. Similarly ticks may have contributed to chick mortality but most chicks became infested at the same time (6-12 July) in each year. By then chicks in 1997 were already too weak to survive; there was an abrupt decline in prey brought to chicks at the beginning of July (Ramos 2000). In colonies on the Great Barrier Reef, Australia, mass chick mortality has occurred in five of the eight years that Roseate Terns were studied since 1976 (Milton et al. 1996). As on Aride, most chicks that died were in an advanced stage of development (Milton et al. 1996). Food shortage seems therefore to be a common feature of Roseate Tern breeding in the Indo-Pacific region. Tropical Roseate Terns exhibit a more pronounced response to fluctuations in prey abundance than Sandwich Terns Sterna sandvicensis (Shealer 1995), and total breeding failure seems more common in Roseate Terns than in other tropical tern species (Smith 1991, Milton et al. 1996, this study).

In tropical environments with poor and seasonally declining food conditions, birds such as Roseate Terns face a conflict. Should they try to lay large eggs or large 
clutches, both of which have benefits, or should they lay as early as possible even if this may mean smaller eggs or smaller clutches? Large eggs may result in either structurally larger hatchlings or hatchlings with more nutrient reserves (Williams 1994). These effects may give nestlings a head start in growth but Roseate Tern chicks on Aride were more likely to fledge from eggs that were either smaller or of similar size to those that produced no young. Therefore, in this population, egg size may not be a good indicator of parental quality, reflecting the fact that egg size may not confer a fitness advantage per se unless it reflects parental quality (Amundsen et al. 1996). With increasing size of egg, the linear growth rate of Roseate Tern chicks on Aride increased significantly, but the results of this study suggest that Roseate Terns do better if they sacrifice egg size/clutch size for earliness of laying. The strategy of the best birds could be to lay as early as possible. It should be noted that this study spanned only two years and that experiments such as cross-fostered clutches would be important to test these aspects.

Three scenarios could be envisaged. (1) If the conditions are poor, as they appeared to have been in 1997 . early breeders will lay one smaller egg as soon as possible (in 1999 laying commenced on 14 June and virtually all Terns abandoned their eggs, stressing the fact that late laying is evidence of a poor food supply - see also Safina et al. 1988). (2) If conditions are medium, as they may have been in 1998, early breeders will lay one larger egg earlier than if condition (1) operates. (3) If conditions are very good early breeders may lay two eggs. Despite such strategies, the presumed experience of the earliest-nesting birds was insufficient to overcome the effects of an acute food shortage in 1997, but early laying increased the chances of successfully raising a chick. Tropical Roseate Terns may be gathering egg nutrients on a day-to-day basis and therefore, in poor years, large eggs would be disadvantageous because they delay laying, resulting in an opposing selection on egg size.

I am indebted to Dr James Cadbury of the Royal Society for Nature Conservation for permission to carry out research work on Aride and for financial assistance to travel there. The friendship and help of the wardens of Aride (Mike Betts and Susan Barclay in 1997, John Bowler and Janet Hunter in 1998), Paul Burton, Rob Malsom, Sharon Johson, Rob Threadgold, Rodney Fauchette and Anna Maria Maul are gratefully acknowledged. Earlier drafts benefited from the comments of Jeffrey Spendelow, Chris Feare, Chris Perrins, Dan Chamberlain, Norman Ratcliffe, Ian Newton and an anonymous referee. Finally I must thank my wife for her continuing support.

\section{REFERENCES}

Amundsen, T., Lorentsen, S.-H. \& Tveraa, T. 1996. Effects of egg size and parental quality on early nestling growth: an experiment with the Antarctic Petrel. J. Anim. Ecol. 65: 545-555.

Ashmole, N.P. 1963a. The regulation of numbers of tropical oceanic birds. Ibis 103: 458-473.

Ashmole, N.P. 1963b. The biology of the Wideawake or Sooty Tern Sterna fuscata on Ascension Island. Ibis 103: 297-364.

Becker, P.H., Finck, P. \& Anlauf, A. 1985. Rainfall preceding egglaying - a factor of breeding success in Common Terns (Sterna hirundo). Oecologia 65: 431-436.

Bolton, M. 1991. Determinants of chick survival in the lesser blackbacked gull: relative contributions of egg size and parental quality. J. Anim. Ecol. 60: 949-960.

Brooke, M. de L. 1990. The Manx Shearwater. London: T. \& A. D. Poyser.

Burger, J., Nisbet, I.C.T., Safina, C. \& Gochfeld, M. 1996. Temporal patterns in reproductive success in the endangered Roseate Tern (Sterna dougallii) nesting on Long Island, New York, and Bird Island, Massachusetts. Auk 113: 131-142.

Coulson, J.C. \& Porter, L.M. 1985. Reproductive success of the Kittiwake Rissa tridactyla: the roles of clutch size, chick growth rates and parental quality. Ibis 127: 450-466.

Cox, D.R. 1970. The Analysis of Binary Data. London: Methuen.

Croxall, J.P., Rothery, P. \& Crisp, A. 1992. The effect of materna age and experience on egg size and hatching success in Wandering Albatrosses Diomedea exulans. Ibis 134: 219-228.

Feare, C.J. 1976. The breeding of the Sooty Tern Sterna fuscata in the Seychelles and the effects of experimental removal of its eggs. J. Zool. Lond., 179: 317-360.

Furness, R.W. 1983. Variations in size and growth of Great Skua Catharacta skua in relation to adult age, hatching date, egg volume, brood size and hatching sequence. J. Zool. Lond. 199: 101-116.

Furness, R.W. \& Birkhead, T.R. 1984. Seabird colony distributions suggest competition for food supplies during the breeding season. Nature 311: 655-656.

Harris, M.P. 1977. Comparative ecology of seabirds in the Galapagos archipelago. In Stonehouse, B. \& Perrins, C. M. (eds) Evolutionary Ecology: 65-76. London: Macmillan.

Hoogstraal, H.H., Wassef, Y., Converse, J.D., Keirans, J.E., Clifford, C.M. \& Feare, C.J. 1976. Amblyomma loculosum (Ixodoidea: Ixodidae) identity, marine bird and human hosts, virus infection, and distribution in the Southern Oceans. Ann Entomol. Soc. Am. 69: 3-14

Lack, D. 1966. Population Studies of Birds. Oxford: Oxford University Press.

Lequette, B. \& Weimerskirch, H. 1990. Influence of parental experience on the growth of Wandering Albatross chicks. Condor 92: 726-731.

Magrath, R.D. 1992. The effect of egg mass on the growth and survival of blackbirds: a field experiment. J. Zool. Lond., 227: 639-653.

Maul, A.M. 1998. Breeding biology and monitoring of three seabird species (Brown Noddy Anous stolidus, Lesser Noddy Anous tenuirostris, Roseate Tern Sterna dougallii) on Aride Island, Seychelles, with special comments on breeding behaviour and biometrics of the Brown Noddy. PhD thesis, Karl-Franzens University, Graz, Austria.

Milton, D.A., Smith, G.C. \& Blaber, S.J.M. 1996. Variable success in breeding of the Roseate Tern Sterna dougallii on the Northern 
Great Barrier. Emu 96: 123-131.

Nisbet, I.C.T. 1973. Courtship feeding, egg size and breeding success in Common Terns. Nature 241: 141-142.

Nisbet, I.C.T. 1978. Dependence of fledging success on egg size, parental performance and egg-composition among Common and Roseate Terns, Sterna hirundo and S. dougallii. Ibis 120: 207-215.

Nisbet, I.C.T. 1981. Biological characteristics of the Roseate Tern Sterna dougallii. Unpublished report for the U.S. Department of Interior, Fish and Wildlife Service, Office of Endangered Species.

Nisbet, I.C.T. \& Cohen, M.E. 1975. Asynchronous hatching in Common and Roseate Terns, Sterna hirundo and $S$. dougallii. Ibis 117: 374-379.

Nisbet, I.C.T. \& Welton, M.J. 1984. Seasonal variations in breeding success of Common Terns: consequences of predation. Condor 86: $53-60$.

Nisbet, I.C.T., Burger, J., Safina, C. \& Gochfeld, M. 1990. Estimating fledging success and productivity in Roseate Terns (Sterna dougallii). Colonial Waterbirds 13: 85-91.

Nisbet, I.C.T., Spendelow, J.A. \& Hatfield, J.S. 1995. Variations in growth of Roseate Tern chicks. Condor 97: 335-344.

Nisbet, I.C.T., Spendelow, J.A., Hatfield, J.S., Zingo, J.A. \& Gough, G.A. 1998. Variations in growth of Roseate Tern chicks: II. Early growth as an index of parental quality. Condor 100: 305-315.

Perrins, C.M. 1970. The timing of birds' breeding seasons. Ibis 112: 242-255.

Perrins, C.M. 1996. Eggs, egg formation and the timing of breeding. Ibis 138: 2-15.

Ramos, J.A. 1998a. Nest-site selection by Roseate Terns breeding on Aride Island, Seychelles. Colonial Waterbirds 21: 438-443.

Ramos, J.A. 1998b. Breeding ecology of Roseate Terns on Aride Island, Seychelles, in 1997. Report to the Royal Society for
Nature Conservation, Lincoln, UK.

Ramos, J.A. 2000. Characteristics of foraging habitats and chick food provisioning by tropical Roseate Terns. Condor. 102: 795-803.

Ramos, J.A., Monteiro, L.R., Solá, E. \& Moniz, Z. 1997. Characteristics and competition for nest cavities in burrowing Procellariiformes. Condor 99: 634-641.

Reid, W.V. \& Boersma, P.D. 1990. Parental quality and selection on egg size in the Magellanic penguin. Evolution 44: 1780-1786.

Safina, C. \& Burger, J. 1985. Common Tern foraging: seasonal trends in prey fish density and competition with bluefish. Ecology 66: 1457-1463.

Safina, C., Burger, J., Gochfeld, M. \& Wagner, R.H. 1988. Evidence for prey limitation of Common and Roseate Tern reproduction. Condor 90: 852-859.

Shealer, D.A. 1995. Comparative foraging ecology of Roseate and Sandwich Terns in Puerto Rico and its relation to breeding performance. PhD thesis, The State University of New Jersey, New Brunswick, USA.

Smith, G.C. 1991. The Roseate Tern Sterna dougallii breeding on the northern great barrier reef Queensland. Corella 15: 33-36.

Spendelow, J.A. 1982. An analysis of temporal variation in, and the effects of habitat modification on, the reproductive success of Roseate Terns. Colonial Waterbirds 5: 19-31.

Warman, S.R. \& Todd, D. 1984. A biological survey of Aride Island Nature Reserve, Seychelles. Biol. Conserv. 28: 51-71.

Williams, T.D. 1994. Intraspecific variation in egg size and egg composition in birds: effects on offspring fitness. Biol. Rev. 69: 35-59.

Received 30 March 1999; revision accepted 21 January 2000 